前頭蓋底手術における嗅神経の温存

中尾 直之

和歌山県立医科大学脳神経外科

\title{
Preservation of the Olfactory Nerve in the Anterior Skull Base Surgery
}

\author{
Naoyuki Nakao, M.D. \\ Department of Neurological Surgery, Wakayama Medical University
}

In the anterior skull base surgery, deteriorations of the olfactory function due to the nerve damage can occur under several conditions of surgical procedures. The surgical procedures include: (1) preservation of the olfactory nerve in cases of bilateral subfrontal, basal interhemispheric, and transbasal approaches, and (2) dissection of the olfactory nerve from anterior skull base tumors. In this article, I show a series of surgical procedures and several tips of preserving the olfactory nerve under these conditions.

(Received November 9, 2018; accepted November 14, 2018)

Key words : skull base, basal interhemispheric approach, transbasal approach

Jpn J Neurosurg (Tokyo) $28: 386^{-} 390,2019$

\section{はじめに}

前頭蓋底腫瘍摘出術において嗅神経の機能が低下また は䘫失する危険性が生じる局面は大きく分けて, (1)手術 アプローチの際の嗅神経剝離・温存操作と(2)前頭蓋底腫 瘍からの剝離操作などが挙げられる。本論文では，これ らの操作における嗅神経機能温存の注意点や工夫につい て解説する。

\section{嗅神経の外科解剖}

嗅神経は嗅球 (olfactory bulb) と嗅索 (olfactory tract) からなり, 嗅球は傍正中の嗅裔に位置するが, 嗅索は中 枢すなわち嗅三角へと近づくにつれてやや外側へと向か $う^{2)}($ Fig. 1). 嗅球から多数の繊細な嗅糸が出て節板の小 孔を貫き鼻腔天蓋部の鼻中隔粘膜に分布する。このた め, 嗅球は節板硬膜に付着した状態で存在し, その周囲

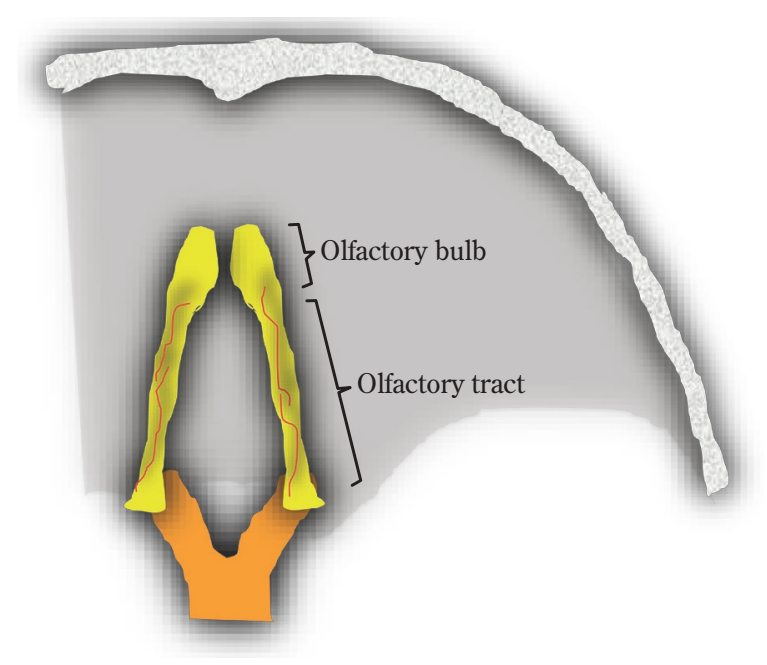

Fig. 1 Image showing the olfactory bulb and tract in the anterior skull base

連絡先：中尾直之, $\overline{\mathbf{T}} 641-8509$ 和歌山市紀三井寺 811-1 和歌山県立医科大学脳神経外科

Address reprint requests to : Naoyuki Nakao, M.D., Department of Neurological Surgery, Wakayama Medical University, 811-1 Kimiidera, Wakayama-shi, Wakayama 641-8509, Japan 

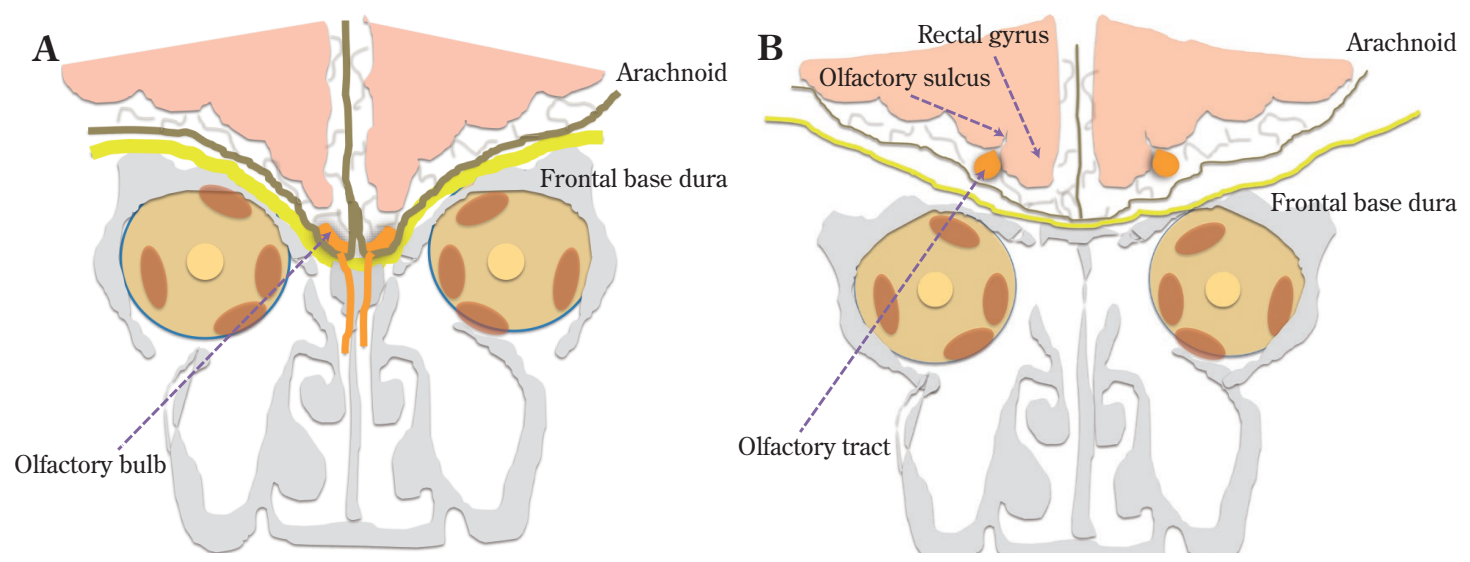

Fig. 2 Coronal view images showing the locative relationship between the olfactory nerve and the frontal lobe

A : The olfactory bulb adheres to the dura covering the cribriform plate.

B : The olfactory tract adheres to the pia mater of the frontal lobe.

にくも膜下腔が存在し前頭葉底面との間に隙間を認める

(Fig. 2A)。一方，嗅索は嗅三角に至るまでその全長にわ たり前頭葉底面の軟膜に付着しており（Fig. 2B）, 頭蓋 底硬膜面とは病的な癒着がないかぎり完全に遊離してい る.

\section{嗅神経の機能温存}

\section{1 手術アプローチに際しての嗅神経温存}

嗅神経機能の温存が問題となる手術アプローチには,

(1)bilateral subfrontal approach や basal interhemispheric approach などの正中から前頭蓋底・傍鞍部に到達するア プローチや(2)篩板を経由して鼻腔・副鼻腔に到達する transbasal approach などがある。これらの手術アプロー チの詳細については他誌の論文を参照されたい(3) 5). こ こでは，嗅神経温存に焦点を絞ってその手術手技につい て解説する。

1. Bilateral subfrontal approach/basal interhemispheric approach

正中から傍鞍部に到達する手術アプローチでは前頭葉 を挙上する前にまず両側の嗅神経を前頭葉底面から遊離 させる.まず嗅球周囲のくも膜の切離から開始する (Fig. 3A)。先に述べたようにこの部分には嗅球周囲に一定の スペースを有するくも膜下腔が存在するため, くも膜の 切離は比較的容易である。嗅窩硬膜に付着している嗅球 からは多数の嗅糸が出て穊板を貫いて鼻腔に分布してい るため, 嗅球周囲のくも膜の切離操作では, 嗅球に触れ ることはもちろん, 決して嗅球に緊張をかけてはならな い. 嗅球は嗅糸の引き抜き損傷防止のため酸化セルロー
スなどを用いてフィブリン糊で嗅窩に固着させる.

嗅球に次いで, 嗅索の剝離に移る。前述のごとく, 嗅 球とは異なり，嗅索は嗅球から嗅神経三角に至るまでそ の全長にわたり前頭葉底面と密着しているため, その前 頭葉底面からの㓦離には注意が必要である。前頭葉底面 に吸引管などで適度に緊張をかけると, 嗅索と前頭葉と の間には arachnoid trabeculae が認められ，これらを周辺 のくも膜とともに切離することにより嗅索を前頭葉から 遊離できる (Fig. 3B)。ここでも嗅索には直接触れない ようにして，嗅索の表面の vasa nervosa には細心の注意 を払う必要がある。嗅索に沿って走行する微細な血管も 温存するように心がける (Fig. 3C)。この嗅索の剝離は, 原則嗅三角まで行う。これら一連の操作はすべてマイク 口鋏による鋭的䟝離で行い, 嗅索と前頭葉との間の arachnoid trabeculae を視認するためにも無血術野の確保 は必須である。

\section{Transbasal approach}

両側前頭開頭および両側眼裔縁を切離した後, 正中の 嗅窩近傍以外の前頭蓋底硬膜を広く剝離挙上する。節板 周囲の骨を蝶形骨平面まで 2 3 mm ダイヤモンドドリ ルを用いて節板をくり抜くような感じで切離する（Fig. 4). 次に, 前方ですでに開放されている鼻腔天蓋もしく は穊骨洞からクーパー剪刀などを挿入して，鼻中隔を前 後方向に切断する。鼻中隔を切離すると, 穊板を鼻腔天 蓋部粘膜とともに一塊として挙上することができる．結 果的に, 節板と鼻腔天蓋部粘膜の塊を硬膜に付着させた 状態で前頭蓋底硬膜が全体的に挙上されることになる (Fig. 5)。このとき, 嗅糸が分布する鼻腔天蓋部の鼻中隔 粘膜をできるだけ大きく節板側に残すことが嗅覚を温存 

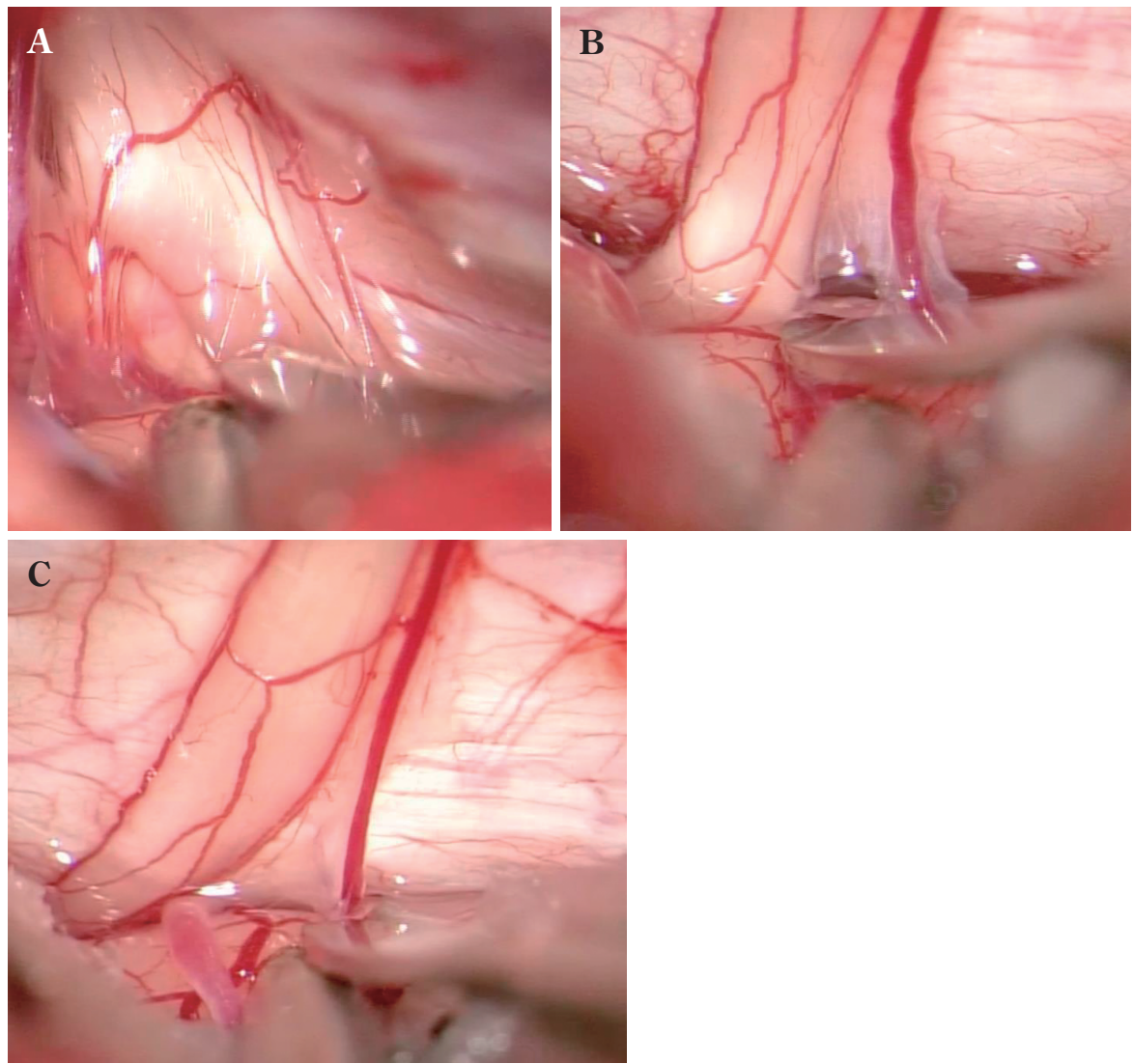

Fig. 3 Dissection of the olfactory nerve

A : Dissection of the olfactory bulb by incising the surrounding arachnoid membrane.

B : Dissection of the olfactory tract from the frontal lobe by cutting the surrounding arachnoid membrane as well as the arachnoid trabeculae intervening between the two structures.

C : Preservation of a blood vessel along with the olfactory tract.
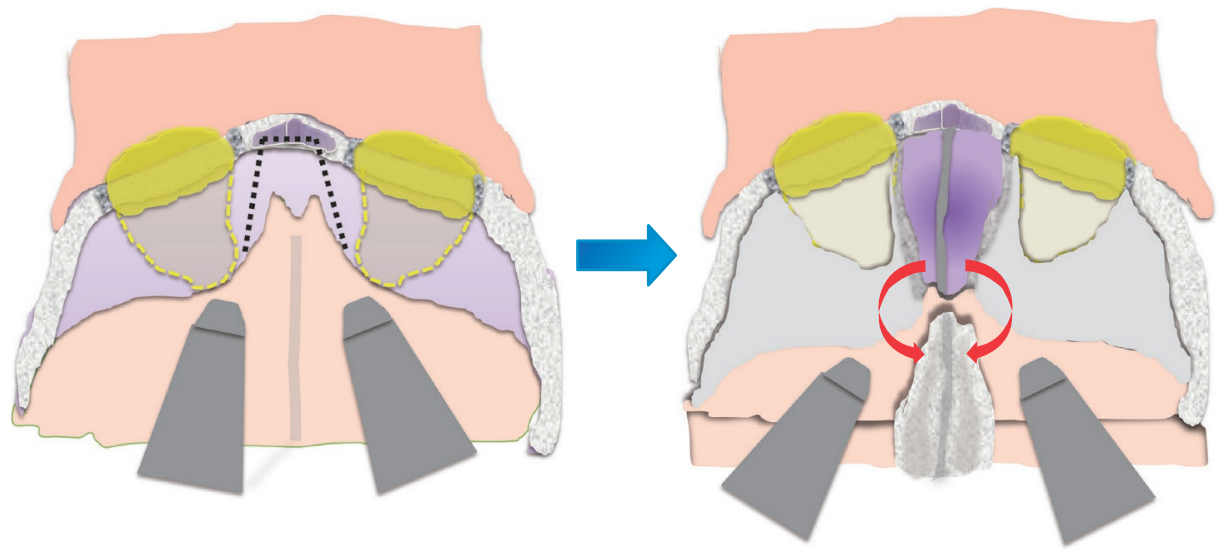

Fig. 4 Images showing the circumferential osteotomies of the cribriform plate

The cribriform plate was incised and turned over. The dotted line represents the range of osteotomies. 


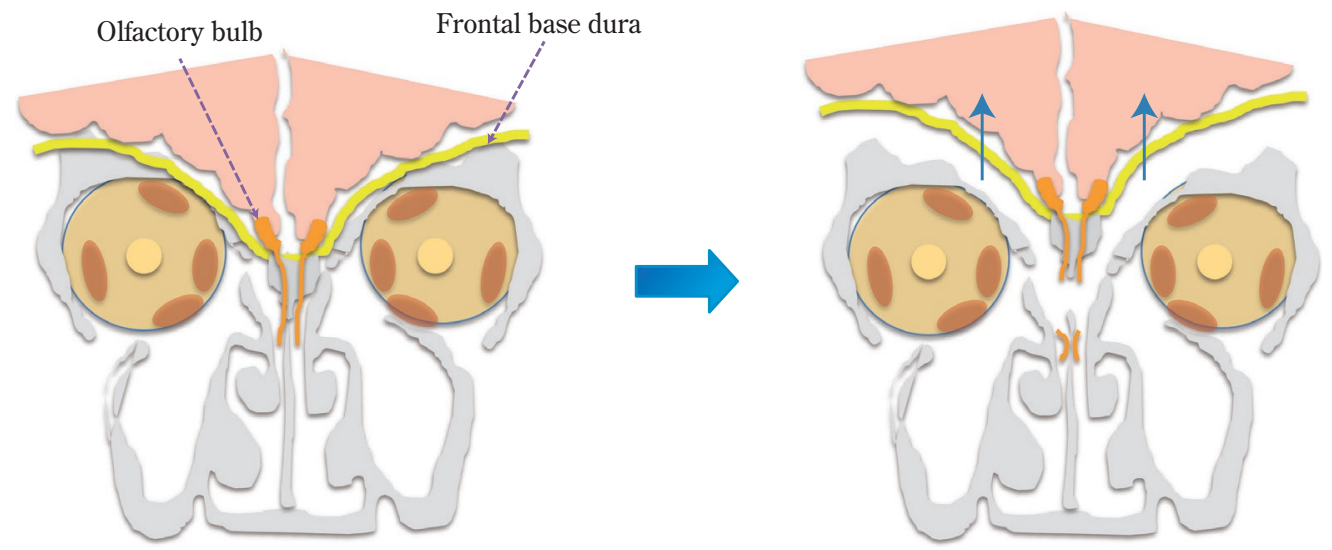

Fig. 5 Preservation of the olfactory fila-containing nasal mucosa attached to the cribriform plate
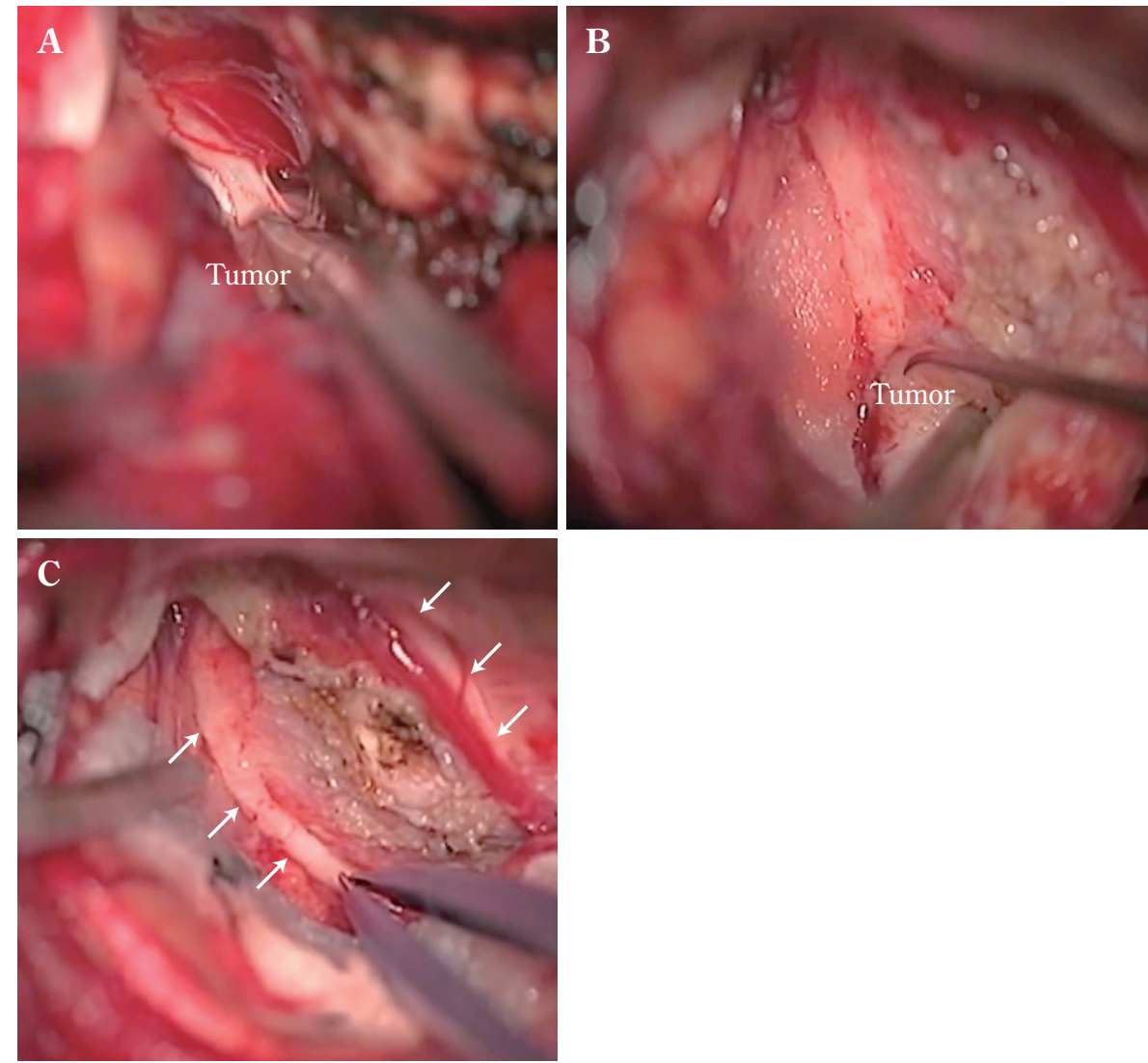

Fig. 6 Intraoperative photograph showing the dissection of the olfactory nerve from the anterior skull base meningioma

A : A sharp dissection of the olfactory tract on the right side.

B : A blunt dissection of the olfactory tract on the left side. Note no clear dissection layer.

C : A final view of the operative field after tumor removal. The bilateral olfactory nerves were morphologically preserved (arrows). Preservation of a blood vessel along with the right olfactory tract. 
するうえで重要である（Fig. 5)。嗅糸の鼻中隔粘膜への 分布範囲は節板から約 $2 \mathrm{~cm}$ までという解剖学的デー夕 が報告されている1)。これら一連の操作では鼻粘膜およ びその周囲から出血を認めるが，嗅覚温存を期するため にも粘膜面の凝固は避ける。

\section{2 前頭蓋底腫瘍との剥離操作}

嗅窩部髄膜腫などではすでに両側の嗅神経障害をきた している場合がほとんどであるが, 術前に嗅覚が温存さ れているょうな場合はもちろん，術中に少しでも嗅神経 の形態が確認できるような場合は温存するよう努める。 嗅神経の剝離には，まず早い段階で付着部と栄養血管の 処置後, 腫瘍の十分な減量を行うことが重要である。十 分な内減圧を行った後, 前頭蓋底から腫瘍を前方から少 しずつ起こしていくと嗅裂に嗅球を認める。そこを起点 として腫瘍から剝離しながら嗅神経走行を追跡する。腫 瘍の大部分をまず摘出し, 嗅神経側に腫瘍の小片を残し た状態で剥離操作を行ってもよい. 内減圧を行わずに腫 瘍を前頭蓋底から起こしていく操作は避けるべきである。

嗅神経と腫瘍との剝離は, これらの境界面の形態学的 な状態によりマイクロ鋏による鋭的剝離とディセクター による鈍的剝離とを使い分ける。内減圧した腫瘍に適度 な緊張をかけると境界面に arachnoid trabeculaeやくも膜 に由来する膜様構造物の介在が確認できる場合がある。 この場合, マイクロ鈇による鋭的剝離を行い(Fig. 6A), その切離はできるだけ腫瘍側で行う。神経表面を走行す る vasa nervosa の温存はいうまでもない. 一方, 腫瘍に 緊張をかけても境界面に介在する構造物が確認できない 場合は嗅神経と腫瘍との位置関係からその境界面をある 程度想定してそのやや腫瘍側をディセクターで鈍的䟝離 する (Fig. 6B)。この場合, 腫瘍を一部神経に付着させ
るのもやむなしとする，また，嗅神経に併走する血管も 可及的に温存する (Fig. 6C).

\section{結 語}

前頭蓋底手術における嗅神経の温存について, 手術ア プローチに伴う場合と前頭蓋底腫瘍との剝離操作の場合 とに分け，その注意点や工夫について解説した。手術ア プローチに伴う場合では, 強拡大での鋭的剝離と微細血 管構造の温存が重要で, これらを実現するための無血術 野が必須である。一方, 腫瘍との剝離では, まずは腫瘍 の十分な内減圧を行い, 鋭的と鈍的剝離の使い分けによ る剝離レイヤーの同定と微細血管構造の温存が重要であ る.

\section{COI 開示}

著者は日本脳神経外科学会への COI 自己申告の登録を完了 しています。

本論文に関して開示すべき COI はありません.

\section{文 献}

1) Dare AO, Balos LL, Grand W: Olfaction preservation in anterior cranial base approaches: an anatomic study. Neurosurgery 48: 1142-1145, 2001.

2) Lang J: Clinical Anatomy of the Head: Neurocranium Orbit $\cdot$ Craniocervical Regions. Berlin, Springer-Verlag Berlin Heidelberg, 1983.

3）中尾直之：傍鞍部腫瘍に対する bifrontal interhemispheric translamina terminalis approach. 脳外速報 $23: 1080^{-}$ 1086, 2013.

4）中尾直之：Bifrontal transbasal approach の基本手技. 脳外 速報 24:960-965, 2014.

5) Speztler RF, Herman JM, Beals S, Joganic E, Milligan J: Preservation of olfaction in anterior craniofacial approaches. J Neurosurg 79: 48-52, 1993.

\section{前頭蓋底手術における嗅神経の温存}

中尾 直之

前頭蓋底腫瘍摘出術において嗅神経の機能が低下または剩失する危険性が生じる局面は(1)手術ア プローチに際しての嗅神経温存操作と, (2)前頭蓋底腫瘍摘出時の剝離操作などに大別できる. 㖵神経 温存操作が必要な手術アプローチは, (1)正中から傍鞍部に到達する bilateral subfrontal approach や interhemispheric approach や, (2)笠板を経由して鼻腔・副鼻腔に到達する transbasal approach など がある. 一方, 前頭蓋底腫場との剝離操作では, ます腫腸の十分な内減圧を行い, 鋭的または鈍的に 腫瘍から嗅神経を剝離する. これらの手術操作における嗅神経温存の注意点や工夫について解説する. 